\title{
A NEW SPECIES OF CYERCE BERGH, 1871, C. KIKUTAROBABAI, FROM YORON ISLAND (OPISTHOBRANCHIA : SACOGLOSSA)
}

$\operatorname{AUTHOR}(\mathrm{S})$ :

Hamatani, Iwao

\section{CITATION:}

Hamatani, Iwao. A NEW SPECIES OF CYERCE BERGH, 1871, C. KIKUTAROBABAI, FROM YORON ISLAND (OPISTHOBRANCHIA : SACOGLOSSA). PUBLICATIONS OF THE SETO MARINE BIOLOGICAL LABORATORY 1976, 23(3-5): 283-288

\section{ISSUE DATE:}

1976-10-30

URL:

http://hdl.handle.net/2433/175935

RIGHT: 


\title{
A NEW SPECIES OF CYERCE BERGH, 1871, C. KIKUTAROBABAI, FROM YORON ISLAND (OPISTHOBRANCHIA: SACOGLOSSA) ${ }^{1)}$
}

\author{
IWAO HAMATANI \\ Tennōji Senior High School of Ōsaka Kyōiku University
}

With Text-figures $1-2$ and Plate I

While sacoglossan opisthobranchs inhabiting caulerpan colonies were searched for in Yoron Island $\left(27^{\circ} 1^{\prime} \mathrm{N}\right.$ and $\left.128^{\circ} 24^{\prime} \mathrm{E}\right)$ of the Amami Islands from March 28 to April 3, 1975, a pretty species, but unknown to the author at that time, was discovered. Later, the detailed examination of this animal revealed that it represented clearly a new species of the genus Cyerce Bergh, 1871 (=Lobiancoia Trinchese, 1881) of the family Caliphyllidae. As only a single species of this genus, $C$. nigricans (Pease, 1866), has been known so far in Japan from Ishigaki Island of the Ryukyu Archipelago by Baba (1936), this finding seems noteworthy. This new species is here named after the author's teacher, Dr. Kikutarō Baba, as it was dedicated to him in celebration of his 70th birthday, July 11 of 1975.

Family Caliphyllidae Thiele, 1931

Cyerce Bergh, 1871

$=$ Lobiancoia Trinchese, 1881

Cyerce kikutarobabai Hamatani, spec. nov.

(Japanese name: Kanoko-urokoumiushi, nov.)

Holotype: The animal collected on thalli of Caulerpa racemosa Weber van Bosse, var. clavifera f. macrophysa Weber van Bosse, growing on a colony of Acropora on the land side of a protecting reef of Yoron Island, on April 1, 1975.

Description: The body (Fig. 1, A) is limaciform, somewhat flattened, and about $9 \mathrm{~mm}$ in total length and about $1.5 \mathrm{~mm}$ in breadth when fully expanded. Dorsolateral papillae are devoid of distinct stalk, flattened, broadly ovate to round in outline, and with both surfaces slightly swollen out. Seven of papillae varing in size are arranged in a single row on each side of the body. Each rhinophore is long, auriculate, bifid in the distal half, and with the groove along the whole length of respective branches and the proximal stalky portion. The oral tentacle is rather

1) A part of the study supported by the financial aid granted from the Ministry of Education, Japan.

Publ. Seto Mar. Biol. Lab., XXIII (3/5), 283-288, 1976.

(Article 21) 
long and with both edges rolled up to assume a cylindrical shape. The eyes are situated close to each other at just the base of rhinophores, very large and visible clearly through the cutaneous layer. The foot is broader than the body in outline, with rounded corners, and the posterior one-third of the sole is clearly separated from the anterior (Fig. 1, G). On the preserved specimen, the anal papilla (Fig. $1, B, a)$ is visible on the dorsal surface between the neck and the pericardial region,

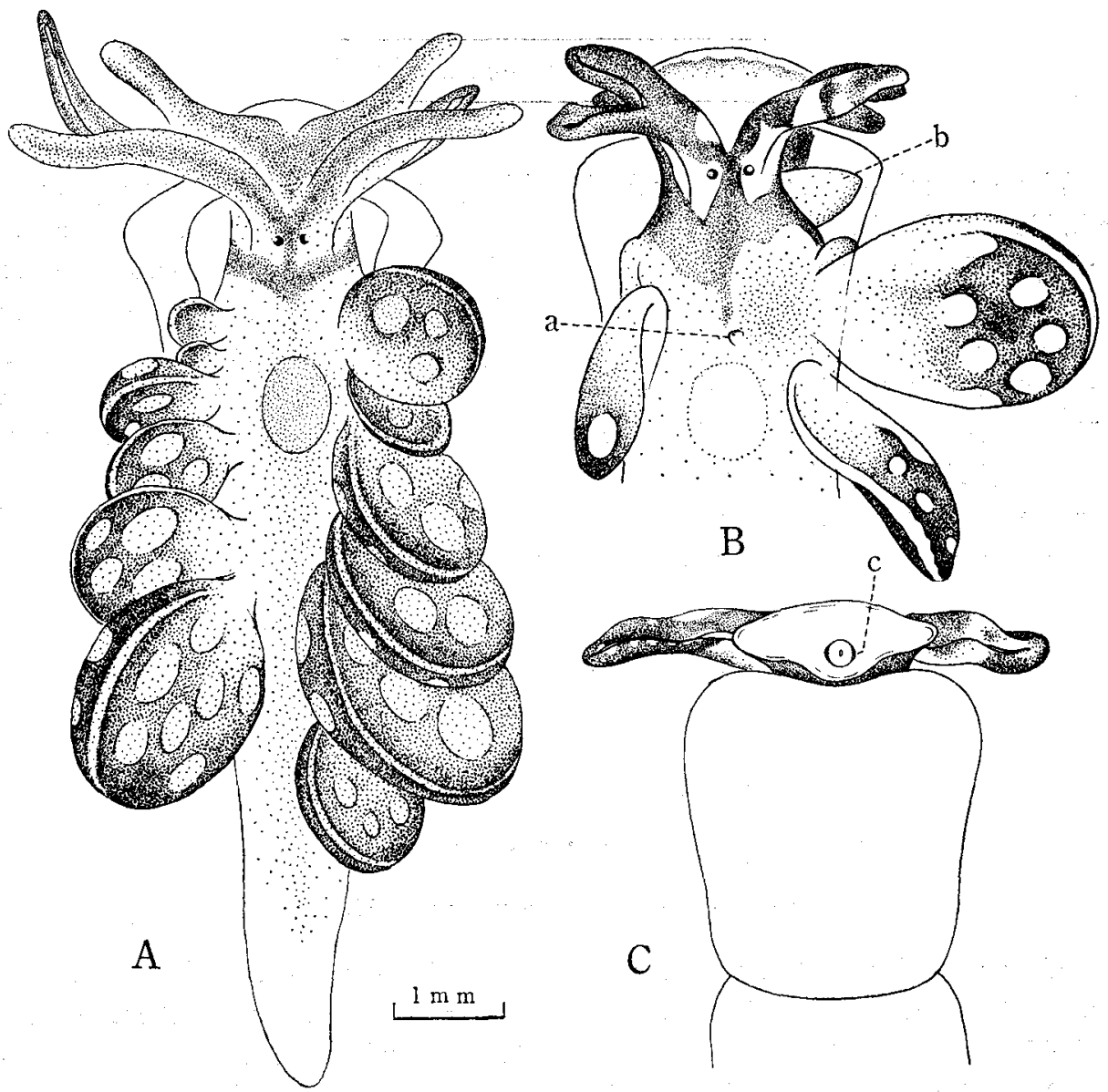

Fig. 1. Cyerce kikutarobabai spec. nov.

A. Living animals, dorsal view.

B. Anterior part of the preserved specimen, dorsal side.

C. The same, ventral side. a: anal papilla. b: penis. c: coloured arch on each side of mouth-lip.

slightly to the right from the median line. The conical penis (Fig. 1, B, b) is situated just behind and below the base of the right rhinophore and seemingly without penial stylet at its top. General body colour of the living specimen is faintly yellowish white, but the cephalic region excepting the area around the eyes, the rhinophores and 
the tentacles are coloured reddish purple and the back looks dimly greyish green as the viscera are seen through the body wall. The dorso-lateral papillae are also coloured reddish purple, more deeply distally but fading away towards the base.

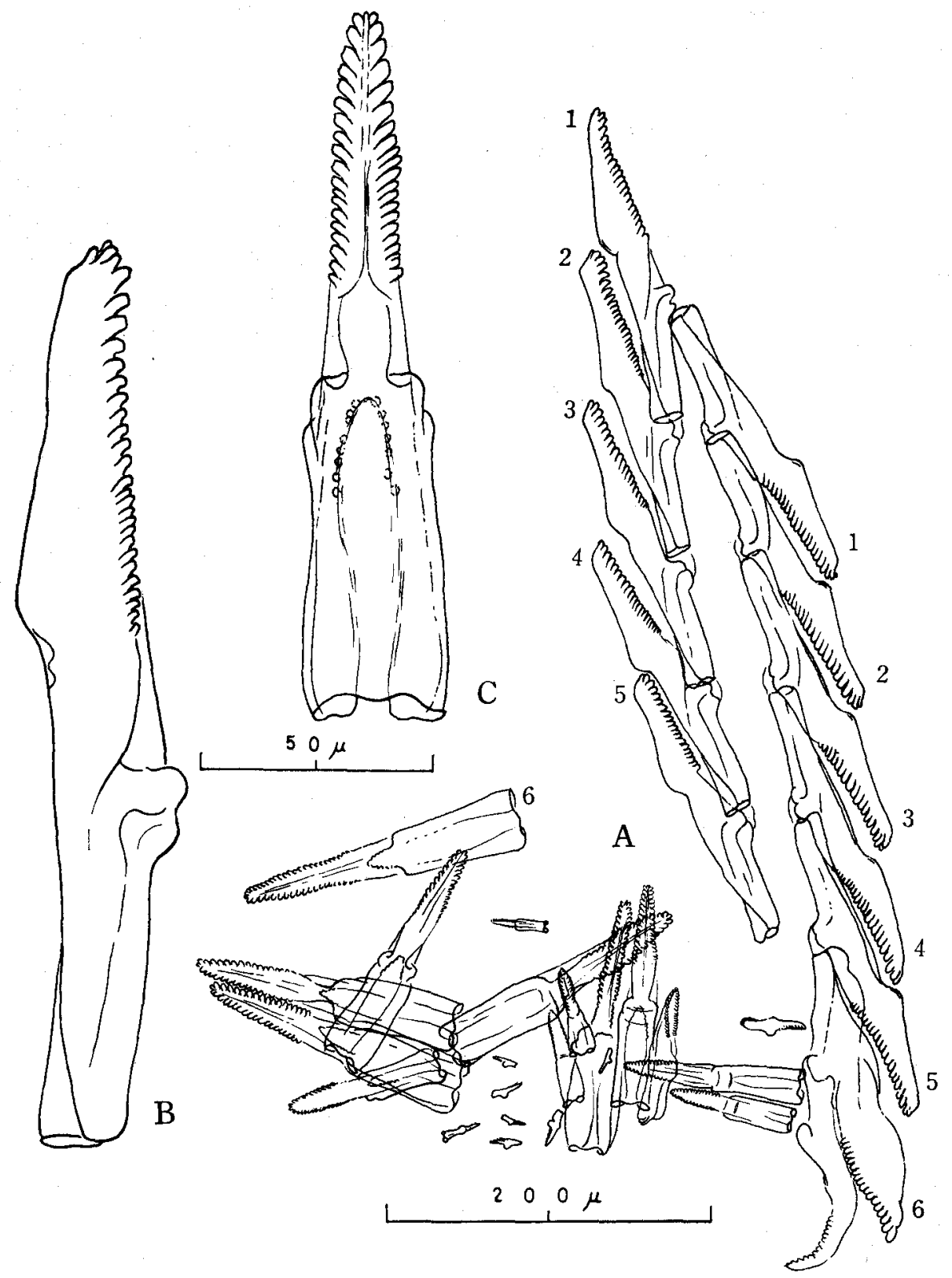

Fig. 2. Cyerce kikutarobabai spec. nov.

A. Radular teeth.

B. An effective tooth, lateral view.

C. A tooth in the heap, dorsal view. 
In addition, they are margined with a yellowish orange band and further furnished irregularly on either surface with several round patches of the same colour, which are rather larger and never raised from the general surface of papillae; these features are quite unique as compared with those in related species. The pericardial region is covered by numerous milky white spots. The dorso-lateral papillae do not contain a part of the female genital organ or branches of the digestive gland. The mouth opening is very small, roundish in shape, and each lateral side of the mouth-lip is characteristically coloured reddish brown in a form of minute arch (Fig. 1, G, c). The radular teeth (Fig. 2) are uniserial as usual in Sacoglossa and consist of 12 teeth in total, 6 in the ascending series and 6 in the descending series, and about 20 teeth of various sizes are contained in the ascus. Each tooth is slender, straight from the tip to the distal end of the base, and the tooth-blade is slightly longer than the base and furnished with about 28 denticles on each side in the effective tooth. The tooth tip seems slightly incised, because the tip is much smaller than the distal denticle on respective sides. Each side of the tooth base is rolled up ventrally so that the base looks cylindrical when seen from the dorsal side. All the teeth are colourless and transparent.

Remarks: The present new species, Cyerce kikutarobabai, resembles the Swennen's specimen (1961, p. 56; fig. 8, a) of C. jheringi Swennen, 1892, which is synonymous with $C$. cristallina (Trinchese, 1881), from Turkey in body colouration. Swennen mentioned in his description of $C$. jheringi: "Colour grey, transparent; head, rhinophores, and cardial region covered with brownish violet pigmentation. The eyes are placed in large unpigmented regions beyond the rhinophores. The compact green liver is dimly visible through the back." C. kikutarobabai is justified, however, to be new to science as it differs from $C$. jheringi in its following features of the dorso-lateral papillae: (1) the papillae are foliaceus, roundish, slightly inflated and with entirely smooth margin; (2) the papillae are margined with a yellowish orange band; (3) the papillae are furnished with rather large patches of the same colour on both the upper and lower surfaces.

\section{REFERENCES}

Allan, J. 1947. Nudibranchia from the Clarence River Heads, north coast, New South Whales. Rec. Austr. Mus., vol. 21, no. 8.

Baba, K. 1936. Opisthobranchia of the Ryukyu (Okinawa) Islands. Journ. Dept. Agric., Kyushu Imp. Univ., vol. 5, no. 1.

Bergh, R. 1871. Malacologische Untersuchungen, Heft. 2, (not seen).

1873. Neue Nacktschnecken der Südsee, malakologische Untersuchungen. I. Journ. Mus. Godeffroy, I. Bd. 1, Heft. 2.

1905. Die Opisthobranchiata der Siboga-Expedition. Siboga- Exped., Monograph 50.

Eliot, C. 1904. On some nudibranchs from East Africa and Zanziber. VI. P.Z.S., vol, 2.

Engel, H. 1927. Westindische Opisthobranchiate Mollusken. II. Bijdr. Dierk., 25.

Marcus, Er. 1965. Some Opisthobranchia from Micronesia. Malacologia, vol. 3, no. 2.

Marcus, Ev. \& Hughes, H. 1974. Opisthobranch mollusks from Barbados. Bell. Mar. Sci., vol. 24, no. 3 .

Marcus \& Marcus 1963. Opisthobranches from the Lesser Antilles. Stud. Fauna Curaçao and other Carib. Isl., vol. 19. 
1967. American opisthobranch mollusks. pt. 1, Tropical American opisthobranchs. Stud. Trop. Oceanogr., no. 6.

___ 1970. Opisthobranchs from Curaçao and faunistically related regions. Stud. Fauna Curaçao and other Carib. Isl., vol. 33.

Miller, M.C. 1969. The habits and habitats of the opisthobranch molluscs of the British Solomon Islands. Phil. Trans. Roy. Soc. B. 255.

Pease, W.H. 1866. Remarks on Nudibranchiata inhabiting the Pacific Islands, with descriptions of two new genera. Amer. J. Conchol, vol. 2, no. 3.

Pelseneer, P. 1894. Recherches sur divers opisthobranches. Mém. cour. Acad. Roy. Belgique, tom. 53.

Portmann, A. 1958. Über zwei wenig bekannte Ascoglossa des Mittelmeers (Gastr. Opisthobranchia). Rev. Suisse Zool., tom. 65, no. 25.

Pruvot-Fol, A. 1954. Mollusques Opisthobranches. Faune de France, 58.

Swennen, G. 1961. On a collection of Opisthobranchia from Turkey. Zool. Mededel., vol. 38, no. 3. 


\section{EXPLANATION OF PLATE I}

A living specimen of Cyerce kikutarobabai spec. nov. from Yoron Island, the Amami Islands, Japan.

Photo I. Hamatani 
Publ. Seto Mar. Biol. Lab., XXIII (3/5), 1976

PLATE I

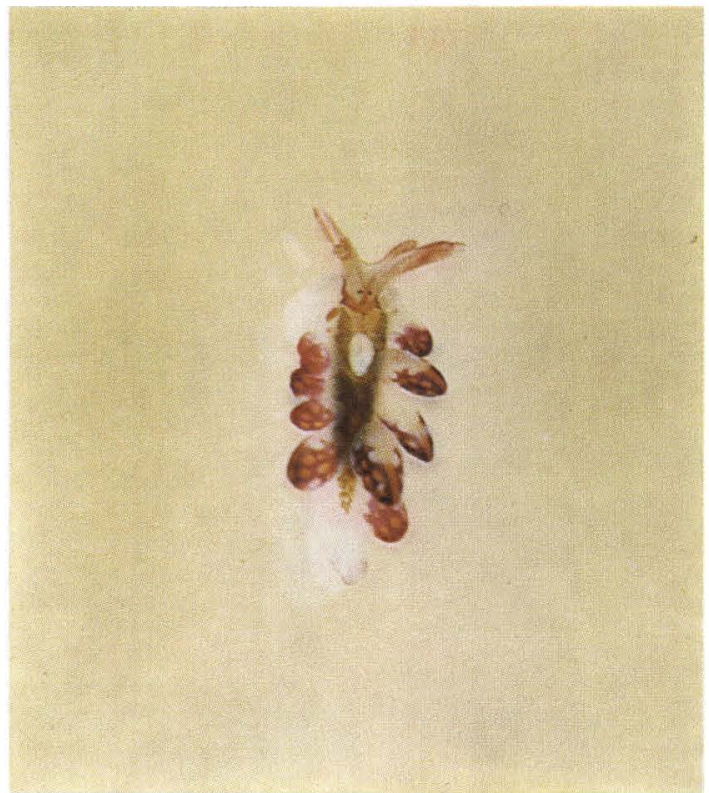

I. Hamatani: A New Species of Cyerce from Japan 